\title{
Community Participation in Education: A Case Study Of Taungzalat School In Kalay,
}

\section{Myanmar}

\author{
Ngun Neh Aung* \\ Niwet Arunberkfa** \\ Mahubul Haque*** \\ Nat Luxchaigul ${ }^{* * * *}$ \\ Kumarashwaran Vadevelu*****
}

\begin{abstract}
This study aimed to investigate the types of community participation in Taungzalat Primary School in Kalay, Myanmar, to provide information in order to develop guidelines, and to enhance community participation in school. A mixed- methods research was employed in this study. Quantitative data were collected from 245 community members using a multiple-response questionnaire. Qualitative data were collected using in-depth interviews and a focus group discussion with 19 participants. The data were analysed using Basic Statistics and content analysis and were integrated through triangulation. The results revealed that parents and community members differently involved in children's learning and school development through all the six types of involvement by Epstein, but their participation was more directly related to student learning improvement than to school development. Community leaders, businesspersons and influential people in the community were involved in school development through PTA, representing the community, in the areas of decision-making, fundraising and school maintenance. Apart from teaching, teachers had roles of facilitating, communicating, networking and mobilizing for school development and students' success. Research showed that the most common form of participation is resource contribution for school development. Therefore, the research suggests that all stakeholders focus on student learning improvement and on resource contribution for school development.
\end{abstract}

Keywords: Community Participation, Education, Primary School, Stakeholders, Myanmar

\section{Introduction}

\subsection{Background and rationale of the study}

It has been known for a long time that community participation in education or school, family and community partnership is important because of its association with a number of positive outcomes for students and school development (Epstein et al., 2018; Hoover-Dempsey, et al., 2005). If community and school work hand in hand and have a good relationship and

\footnotetext{
* Social Development Department, Faculty of Humanities and Social Sciences, Prince of Songkla University, Patthani, Thailand.

${ }^{* *}$ Asst., Prof. Dr. Social Development Department, Faculty of Humanities and Social Sciences, Prince of Songkla University, Patthani, Thailand

*** Ph.D. Faculty of Law and International Relations, Universiti Sultan Zainal Abidin (FUHA-UNISZA), Malaysia

${ }^{* * * *}$ Prof. Dr. Social Development Department, Faculty of Humanities and Social Sciences, Prince of Songkla University, Patthani, Thailand

${ }^{* * * * *}$ Ph.D. Social Sciences Department, Faculty of Humanities and Social Sciences, Prince of Songkla University, Patthani, Thailand

Corresponding Email: ngunnehaung1988@gmail.com
} 
communication, children will succeed in their academic achievements as well as in their later life (Cole, 2006; Topper \& Powers, 2013). Studies have revealed that community participation in education is highly correlated with students' achievement in academic areas (Mautone, et al., 2015), social life (Driessen et al., 2005), and behaviour (Reynolds, et al., 2001). Furthermore, if schools invite and welcome stakeholders such as parents and community members to be involved in education, students' performance increases (Driessen, et al., 2005). Therefore, community plays a vital role in children's education, and has responsibility to assure high-quality education for all students.

By increasing community involvement, the areas like students' attendance, attitudes, behaviours and higher aspirations can be positively changed (Topper \& Powers, 2013). If community members such as parents actively participate in school activities, children will actively engage in learning and gain measurable outcomes (Cheung, \& Pomerantz, 2015; Mautone, et al., 2015). McNeal (2012) also stated that increasing community participation decreases students' negative behaviours, simultaneously promoting positive social development in school. Evaluation of community involvement in primary schools shows that community involvement significantly affects student performance and contributes to the mental capacity, social and cognitive behaviour of students (Hornby, 2011; Nitecki, 2015). Studies also show that communities and parents are essential for students' preparation before the classes, and parents who are actively involved in home and school activities increase the learning outcomes of their children. Ultimately, parents who assist students at home with homework not only contribute to their child's preparedness, but also to their ability to articulate prior knowledge and grasp new concepts (Henderson, 2007; Mautone, et al., 2015; Rodriguez, et al., 2014).

Having realized the benefits of community participation, the government of Myanmar (GoM) encourages schools to develop strategies of community participation and implement them in schools, and GoM strongly suggests that community members actively participate in the matter of education and upgrade effective community-school communication and relationship (Win, 2014). The non-governmental organization Community-Based Education Development Association is also working together with GoM in order to increase community members' roles in fundraising, maintenance and construction of school buildings; moreover, parents are being trained to be able to cooperate with school more effectively in educating children (Bray, 2000).

Although there is an endeavour from the governmental and non-governmental organizations, a clear strategy or guideline on community participation to be implemented and practiced has not been provided yet. In fact, due to the lack of information of strategy and guideline, schools in Myanmar seem to fail to cooperate in such attempts of involving community members in schools )Win, 2014(. As a result, it can be assumed that community involvement will continue to be a major struggle from primary schools to high schools in Myanmar. Moreover, no research on the level of community participation has been reported in Myanmar. Relationship between the community and the school very much depends on how the schools approach the community and what strategies schools implement to increase community participation in education. However, due to the result of lack of information and effective strategies, it is critical to investigate the types of community participation in the schools of Myanmar and barriers to participation, and provide the guidelines of community participation which will benefit schools.

\subsection{Research questions and objectives}

\subsubsection{Research questions}

The following research questions guided the study: 
i. What are the types of community participation in detail observed in the selected school?

ii. What is the formation, structure and administration system of the studied school as well as those of Taungzalate community.

\subsubsection{Research objective}

The study aimed to investigate in detail the types of community participation in the Taungzalat school in Kalay, Myanmar. In addition, the research studied the school formation, structure, and administration system, as well as the Taungzalat community formation, structure, and administration system.

\subsection{Benefit of the study}

This study helped understand forms of community participation in primary school, and the results could be used to develop the guidelines to increase community involvement in schools, which will, in turn, improve students' achievement. Moreover, not only do these results benefit the school administrators, principals, all the stakeholders including students, community leaders, and parents, but also this issue is critical for educational policy in general.

\section{Literature Review}

\subsection{Six typologies of Epstein's model of community participation}

One of the most popular models for parent and community involvement is Epstein's model of community participation that is composed of six types of well-structured parent and community involvement activities (Washington, 2016). The six types are:

1. Parenting - parents set up conditions that help children learn at home and school.

2. Communication - to construct a strong mean of school-to-home and home-school communication that allows parents/ guardians to learn about children's progress at school, and the school/ teachers to learn child progress while learning at home.

3. Volunteering - to help school by organizing and recruiting parents' help and support.

4. Learning at home - to give family members suggestions and information on how to help children at home, and provide them with other curriculum-related activities, plans, and decisions at home.

5. Decision - to encourage parents and community members to participate in school decisions and recruit parent-leaders and representatives to attend school meetings; and

6. Working with communities - to integrate and recognize resources as well as services and labors in the community to enhance school programs, student learning and family practices )Epstein, 1995, 1997, qtd. in Washington, 2016 (.

The first type is to help community members, parents and all families to establish home environments that support children's learning at schools (Epstein, 1987). This type has involvement activities in which parents can involve helping children for their basis needs of children such as preparing their child for school and making sure that the kid is ready to learn at school (Smith \& Brahce, 1962). In addition, the activities in the first type are quite simple, but they help establish a home environment where children enjoy learning and doing their school exercises and homework before and after school (Vera et al., 2012). 
The second type, learning at home, is to provide information and ideas to community members and families about how to help students at home with homework and other curriculum-related activities, decisions, and planning (Epstein, 2010). The activities in this type allow children to discuss and share their homework and ideas with parents as well as family, which helps build a two-way communication between parents and teachers regarding the curriculum and other school-related activities (Williams, 2017). When parents actively work together with children at home, children, in turn, become more active to involve in setting goals for educational success and planning postsecondary education experience (Epstein \& Sheldon, 2002; Washington, 2016).

The activities of the second type consist of information through which community members and parents can help children with homework in order to improve the knowledge and skills of children in all subjects (Epstein \& Sheldon, 2002). When students start to discuss what they learned at school and parents explain the lessons they did not understand during classes, children's knowledge and skills would improve and their performance on homework and tests will get better. In return, parents will be familiar with the curriculum when "Learning at Home" activities are effectively developed and implemented (Epstein, 2010; DerrickLewis, 2001). Benefits of type 2 can be huge to students but it is difficult to design and implemented (Epstein, 2010). However, if learning at home activities are not designed and implemented, the consequences can be bad, as parents will not be provided information about curriculum and the ways to assist their children, which will decrease parent involvement (Epstein \& Sheldon, 2002). It is always good to consider the activities through which parents can help their children at home, because they are a significant tool for encouraging students to complete the homework or assignments and other activities and, furthermore, parents can help students set the goals for education and the aims for the future (Mombourquette, 2007; Epstein, 2010).

The activities in the second type of parent involvement are activities related to school, and the research showed that home activities seem to be more effective, especially to minority parents (e.g. ELLs' Spanish-speaking parents), rather than active school involvement (Altschul, 2001). Agreeing to that idea, Vera (2012) also said that minority parents who are facing language barriers feel most comfortable with the fourth type of involvement. As this type benefits parents, teachers and schools may also profit from activities of this type by experiencing a boost in parent involvement and support of the educational process (Epstein, 2010).

The third type, communication, is to design effective forms of school-to-home and home-to-school communication that enable parents to learn about school programs and their children's progress in schools as well as teachers to learn about how children do at home (Epstein, 2010). By building effective home-school communication, parents can give the best support to their children in their learning (El Nokali et al., 2010). As activities in the third type can progress communication barriers plague, they are effective, especially to English Language Learner parents. Vera (2012) suggested that school should implement communicating activities by creating a positive forum of two-way communication between teachers and parents. If parents and teachers speak different languages, it takes cultural sensitivity and appropriate language aids in order to successfully build two-way communication between parents and teachers (Baird, 2015).

The fourth type, volunteering, is to recruit and organize community members and parent help and support (Epstein, 2010). It is about parent voluntarily being involved in school activities on behalf of their children (Epstein, 2010; Williams, 2017). If schools develop several activities in which community members and parents are voluntarily involved, communication participation will surely increase in school, which will in turn result in higher learning outcomes. As parents and community members become more involved, they will get along better with school, principal and teachers; as a result, they will feel more confident and comfortable with each other. Moreover, teachers will encourage to involve parents and families in many ways, not just as volunteer and parents will more likely participate willingly (Washington, 2016). Such parent volunteer activities are resources to the school that promote self-confidence and socialization among children (Banerjee, Harrell, \& Johnson, 2011). 
The fifth type, decision making, is to include community members, parents and families in school decision making, to have parent leaders and representatives in school meetings (Epstein \& Sheldon, 2002; Williams, 2017). By involving community members in educational leadership roles, the represented leaders may become the information sources to family and community members in order to support the school (Epstein, 2010; Washington, 2016). If parents and teachers collaborate in leading school with some goal and interest, children will benefit with experience enhancement (Epstein \& Sheldon, 2002; Mombourquette, 2007).

Activities in the fifth type allow community members to contribute their ideas concerning about school improvement, policies and plans. Because most of family and community members do not really want to be part of the committees or the leading roles but want to raise their voices and want someone will present their ideas and opinions for them, it is crucial to appoint parent leaders who can be the representatives of family and community and who will serve on the school council, school improvement teams, parent-teacher association (PTA), parent-teacher organization (PTO), advisory group and committees (Washington, 2016). Appointed community leaders should be active and must get ideas from parent, family and community member in order to share with the school. They must also be active at sharing the information of the school's decision, programs and activities to parents, family and community members (Epstein \& Sheldon, 2002).

When choosing community leaders to involve them in school decision making, it is important to select parents from all racial, ethics, socioeconomic, and other groups within the school population (Derrick-Lewis, 2001). They must also be trained appropriately so that their leadership skills will improve and they will be able to represent other families properly (Epstein \& Sheldon, 2002). Moreover, Epstein and Sheldon suggested that for the upper level, school should also have student representatives in decision making. When parents are involved in decision making, actively collaborating with school, teachers and school will know what the stakeholders want. They will gain insight to families' perspectives regarding to school policies and school decision making. In turn, parents will respect teachers and understand school policies and decision making better; moreover, their leadership skills will also be improved. As a result, school performance and students' achievement will get higher (Williams, 2017).

The sixth and final type, collaborating with the community, is to identify and integrate resources as well as services from the community in order to strengthen school programs, family practices, and students' learning (Epstein, 2010). Schools will get support from the community, and their relation with business in the community will be reinforced if schools' collaboration with community is effective (Williams, 2017).

School community is a component of everybody who has a great interest in improving the quality of education or in providing quality education (Derrick-Lewis, 2001). Furthermore, school community is not just parents and families, but it also refers to the various individuals, groups, businesses, and institutions that invest in the welfare and vitality of a public school and its community - i.e., the neighbourhoods and municipalities served by the school (Epstein, 2010). The involvement of community will bring a great amount of beneficial services to students and schools such as business partnerships, cultural organizations, healthcare, recreational centres, senior citizen programs, faith-based programs, governmental agencies, and other groups (Washington, 2016). Furthermore, services including mentoring, tutoring after school care, social development activities and volunteer services to support school can be involved. Collaboration with community can also help improve children's skills, enrich their knowledge and talent through curricular and extracurricular experience and exploration. Moreover, children will also gain self-confidence and ownership of the community they grow up and live in, as they participate in collaborating activities in the community (Epstein, 2010; Williams, 2017).

Collaboration with community will also enhance school staff members', teachers' and administrators' knowledge of the community and make them aware of the community resources that they can use for curriculum development and enriching 
students' experience (Epstein, 2010; Mombourquette, 2007). As the benefit of the services offered by the community is huge, especially to administrators assisting parents and children, school should really consider how to increase community involvement. Epstein's theory of overlapping spheres provides a model of the involvement of the family, school and community in education of children (Epstein \& Sheldon, 2002; Washington, 2016).

To (2016) developed a framework to measure the degree or level of community participation in education by integrating Bray's (2000) framework and Epstein's (2010) theory. According to Bray (2000), participation includes genuine participation and pseudo-participation. Genuine participation is the process by which participants voluntarily participate in the development process with equal rights, power and influences in decision making. In contrast, in pseudo-participation, people participate only in counselling and collecting information needed to complete development, research, or surveys. Participants have no authority or authority. Between pseudo-involvement and genuine involvement, there are (1) use of services, (2) donation of resources, (3)attendance at meetings, (4) counselling, (5) involvement in service delivery, (6) delegated power, and (7) real power. In order to measure parent or community participation in education, these two theories - Bray's (2000) $f$ and Epstein's (2010) - were integrated by To (2016) as shown in Table 1.

Table 1. Integrated framework by to (2016)

\begin{tabular}{|c|c|c|c|c|c|c|c|}
\hline \multirow[t]{2}{*}{ Form of Participation } & \multicolumn{2}{|c|}{ Pseudo Participation } & \multicolumn{5}{|c|}{ Genuilhe participation } \\
\hline & $\begin{array}{c}\text { Use of } \\
\text { service } \\
\text { )1( }\end{array}$ & $\begin{array}{c}\text { Resources } \\
\text { Contribution } \\
\text { 22( }\end{array}$ & $\begin{array}{c}\text { Attendance } \\
\text { at meeting } \\
\text { )3( }\end{array}$ & $\begin{array}{c}\text { Consultation } \\
\qquad 4(\end{array}$ & $\begin{array}{l}\text { Involvement } \\
\text { in delivery ) } 5 \text { ( }\end{array}$ & $\begin{array}{c}\text { Delegated } \\
\text { power } \\
\text { )6( }\end{array}$ & $\begin{array}{c}\text { Real } \\
\text { power } \\
\text { )7( }\end{array}$ \\
\hline 1. Parenting & & & & & & & \\
\hline 2. Learning at home & & & & & & & \\
\hline 3.Communicating & & & & & & & \\
\hline 4. Volunteering & & & & & & & \\
\hline 5. Decision-making & & & & & & & \\
\hline 6. Collaborating & & & & & & & \\
\hline
\end{tabular}

\section{Methodology}

\subsection{Research Design}

This is a single case study employing a mixed-methods research.

\subsection{Population and Sample}

Taunghzalat Primary School (TPS), Kalay, Myanmar was chosen as the research site. There were 700 community members in the 
community of the selected primary school. For quantitative phase, Taro Yamane Formula $n=N / 1+N(e) 2$ was applied, where $n=$ sample size, $\mathrm{N}=$ population, $\mathrm{e}=$ acceptable of sampling error, and $\mathrm{p}<0.05,229$ participants $(\mathrm{n}=229)$ meeting the inclusion criteria were recruited using random sampling method. For qualitative data, 19 participants, who met the inclusion criteria, were interviewed, including the school principal, 5 teachers, 3 community leaders, 8 school committee members, and 3 parent who had experience in participation.

\subsection{Research Instruments}

For the quantitative phase, a multiple response questionnaire was used to collect the data. The questionnaire was piloted with 30 samples, and the Cronbach's Alpha value for the reliability was .75. Content validity was tested by three experts, and the result was acceptable. For the qualitative phase, in-depth interviews, focus-group discussion and observation were used to collect primary data. Secondary data were collected from the documents and records.

\subsection{Data Collection}

After questionnaire adjustment was carried out, it was translated, duplicated, and sent to the participants along with a cover letter introducing and explaining the purpose of the study stressing the confidentiality of responses and enlisting the response of the participants. Afterward, in-depth interviews were conducted, followed by focus-group discussion and observation. With permission, the secondary data were collected from documents and record of the community and school.

\subsection{Data Analysis Procedure}

Quantitative data were analysed using Basic Statistics: mean, frequency and percentage. After conducting the interviews, the researcher transcribed Burmese conversations of the interview, which were then translated into English. The data from interviews, documents and record were coded and analysed using content analysis. The results of quantitative and qualitative data analysis were integrated using triangulation. The degree of community participation was measured using the model by To (2016) that integrated Epstein's types of involvement (Epstein, 2010) and Bray's Framework (Bray, 2000).

\subsection{Ethical Considerations}

This study followed the concept of Smith's (2003) "Five Principles for Research Ethics" and the guidelines of MoE, Myanmar to protect participants' confidentiality.

\section{Results}

\subsection{Quantitative Research}

\subsubsection{Characteristics of Survey Respondents}

A total of 229 subjects, students' parents and other community members working in the leading roles, participated in this study. Of the subjects, 75 (32.8\%) were males with mean age of 44.8 , and 154 (67.2\%) were females with mean age of 34.5 . $1.3 \%$ of the subjects had a master's degree level, and $18.8 \%$ had bachelor degrees, while the majority (72.1\%) had high school levels of education. $7.9 \%$ did not mention their educational level, and 45 (19.7\%) respondents did not want to mention their occupation. A majority (18.3\%) of the respondents were unemployed. The reason why they were unemployed was that they were the mothers in the family and dependent on the husbands. The second most significant occupation was famer (13.1\%), followed by home 
business (6.5\%) and businessperson (5.6\%). There were also few civil servants (2.6\%), lawyer (.4\%), drivers (.9\%), carpenter (4.3\%), teachers (3.5\%), and religion leaders- pastors (2.6\%), and Roman Catholic sister (.9\%) (See Table 2).

Table 2. Gender, age, education level and occupation of survey respondents

\begin{tabular}{|c|c|c|c|}
\hline & Frequency & Peecent & Mean \\
\hline \multicolumn{4}{|l|}{ Gender } \\
\hline Male & 75 & 32.8 & \\
\hline Female & 154 & 67.2 & \\
\hline \multicolumn{4}{|l|}{ Age } \\
\hline Male & - & - & 44.8933 \\
\hline Female & - & - & 34.5519 \\
\hline Education Level & 165 & 72.1 & \\
\hline High school & 43 & 18.7 & \\
\hline Bachelor Degree & 3 & 1.3 & \\
\hline Masters' Degree & 18 & 7.9 & \\
\hline \multicolumn{4}{|l|}{ No Response } \\
\hline \multicolumn{4}{|l|}{ Occupation } \\
\hline Farmer & 30 & 13.1 & \\
\hline Driver & 2 & .9 & \\
\hline Home business & 15 & 6.5 & \\
\hline Business person & 13 & 5.6 & \\
\hline Civil servant & 6 & 2.6 & \\
\hline Laborer & 9 & 3.9 & \\
\hline Lawyer & 1 & .4 & \\
\hline Dependant & 85 & 37.1 & \\
\hline Pastor & 6 & 2.6 & \\
\hline Catholic sister & 2 & .9 & \\
\hline Teacher & 8 & 3.5 & \\
\hline Carpenter & 10 & 4.3 & \\
\hline No response & 42 & 18.3 & \\
\hline
\end{tabular}




\subsubsection{Types of community participation in school}

The results of the study showed that various groups of community members of the Taungzalat Primary School, comprising of teachers, students' parents, local authorities (community leaders), businesspersons and students, participated in children's learning and school development. All the stakeholders had different perspectives towards community involvement and involved in education differently. The different ways of participation included activities such as parenting, learning at home, communicating, volunteering, decision making and collaborating.

\subsubsection{Parenting and Learning at Home}

Table 3. Parenting \& Learning at Home $(n=229)$

\begin{tabular}{|c|c|c|}
\hline Parenting Activities \& Learning at home activities & Frequency & Percentage \\
\hline Sending children to school and receiving them from school & 178 & $77.7 \%$ \\
\hline Make sure students attend classes & 222 & $96.9 \%$ \\
\hline Enroll children at school & 166 & $72.5 \%$ \\
\hline Feed children nutritious foods & 2 & $.9 \%$ \\
\hline Prepare food for children & 209 & $91.1 \%$ \\
\hline Help children clean cloth and body & 220 & $96 \%$ \\
\hline $\begin{array}{l}\text { Encourage child to study, and help children with their homework and check } \\
\text { if they learn }\end{array}$ & 222 & $96.9 \%$ \\
\hline Send children to tutorial school & 2 & $.9 \%$ \\
\hline Hire qualified person to teach children at home & 7 & $3.1 \%$ \\
\hline teaching children & 181 & $79 \%$ \\
\hline Check child's notebook & 195 & $85.6 \%$ \\
\hline Ask children to study with their friends & 1 & $.4 \%$ \\
\hline
\end{tabular}

In terms of parenting and learning at home activities, community members, especially parents, caregivers, or siblings of children involved in children's schooling by making education available or accessible to the children. As can be seen in table 3,77.7\% of parents reported that they sent children to school and received them from school; $72.5 \%$ of them helped students enrol at school, and $96.9 \%$ of them made sure student attend classes daily. Furthermore, $96.9 \%$ of parents always encouraged their children to study at home and helped with their homework; $85.6 \%$ of them always checked their children's notebooks, and $79 \%$ of them taught their children at home. Interestingly, a few parents (3.1\%) hired qualified teachers to teach their children at home. 
Moreover, a few parents (.9\%) who could not help their children at home would ask their children to take extra classes after school to learn more and understand their lessons better. Interestingly, few parents let their children study with their friends so that they can help each other (See Table 3).

\subsubsection{Communicating}

Table 4. Communicating $(n=229)$

\begin{tabular}{|c|c|c|}
\hline Communicating Activities & Frequency & Percentage \\
\hline \multicolumn{3}{|c|}{ How do you communicate with school? } \\
\hline go to school & 199 & $86.9 \%$ \\
\hline phone call & 150 & $65.5 \%$ \\
\hline attend meeting & 138 & $60.3 \%$ \\
\hline by texting & 1 & $.4 \%$ \\
\hline by letter & 1 & $.4 \%$ \\
\hline never & 6 & $2.6 \%$ \\
\hline \multicolumn{3}{|l|}{ How often do you go to school? } \\
\hline everyday & 83 & $36.2 \%$ \\
\hline once a week & 4 & $1.7 \%$ \\
\hline more than once a week & 91 & $39.7 \%$ \\
\hline once a year & 10 & $4.4 \%$ \\
\hline whenever invited & 43 & $18 \%$ \\
\hline never & 6 & $2.6 \%$ \\
\hline \multicolumn{3}{|c|}{ Purposes or reasons of going to school } \\
\hline to discuss about children & 171 & $75.1 \%$ \\
\hline \multicolumn{3}{|l|}{ learning } \\
\hline to enrol children & 166 & $72.5 \%$ \\
\hline send or receive children & 179 & $78.2 \%$ \\
\hline attend meeting with teacher & 136 & $59.4 \%$ \\
\hline emergency call from the school & 4 & $2.1 \%$ \\
\hline )e.g. child is sick( & & \\
\hline
\end{tabular}


As shown in table 4, community members, especially parents and family members of children communicated with school in several means. The most common means for home-school or community- school communication were going to school to discuss with the teachers (86.9\%), phone call (65.5\%), attending meeting arranged by teacher (60.3\%). Other means of communication done by parents were texting (.4\%) and letter (.4\%). Surprisingly, there are a few parents (2.6\%) who never contact with school.

\subsubsection{Volunteering}

Table 5. Volunteering $(n=229)$

\begin{tabular}{lcc}
\hline Volunteering & Frequency & Percentage \\
\hline Volunteer in school committee board & 195 & $85.6 \%$ \\
\hline Go to special events at school & 220 & $96.1 \%$ \\
\hline Involve in every school activity & 180 & $78.6 \%$ \\
\hline Help maintain school building and cleaning the school compound & 202 & $88.2 \%$ \\
\hline
\end{tabular}

Another key finding was that there was a volunteering team in the studies school, in which 8-community members volunteered by assisting teachers or teaching in the classroom, and 16 community members voluntarily took leading positions in school board committee. Moreover, other community members including parents, students, businesspersons and community leaders voluntarily participated by going to special events at school )96.1\%(, helping maintain school building and cleaning the school compound )88.2\%(, involving in school committee board )85.6\%( and school activities )76.6\%(. )See Table 5(

\subsubsection{Decision making and collaborating}

Table 6. Decision Making and Collaborating $(n=229)$

\begin{tabular}{lll}
\hline Kinds of Community Contribution & Frequency & Percent \\
\hline Raise opinion and give advice on school related issues in meeting. & 105 & $45.9 \%$ \\
\hline Participate as school council and committee members in decision making. & 16 & $6.8 \%$ \\
\hline
\end{tabular}




\begin{tabular}{lcc}
\hline Involve in planning and evaluating school programs & 9 & $3.9 \%$ \\
\hline Contribute Money & 106 & $46.3 \%$ \\
\hline Contribute materials & 59 & $25.8 \%$ \\
\hline Contribute labour & 142 & $62.0 \%$ \\
\hline
\end{tabular}

In connection with decision making and collaboration as shown in table 6, this study found that parents, school supported committees, community leaders, and the churches in the community participated in school development. However, their participation in decision-making could be assumed as low even though their opinion were asked (45.9\%). $6.8 \%$ of the community reported to have participated as members of school committee, and 3.9\% in school program planning and evaluating. Community members mostly promoted education by contributing financial help )46.3\%), labour (62.0\%), and materials )25.8\%).

When analyzing the levels of community involvement based on To's table, community participation activities regarding parenting and learning at home in education programs were consultations, occasional meetings, and personal communication with teachers. Therefore, parenting and learning at home fell at the level of consultation )See figure 1(. Communicating and volunteering benefited school and children in a way of delivering service; therefore, they fell in the level of service delivery in the integrated model of To. Community involvement in collaborating and decision-making activities mentioned above were at the level of delegated power as shown in figure 1.

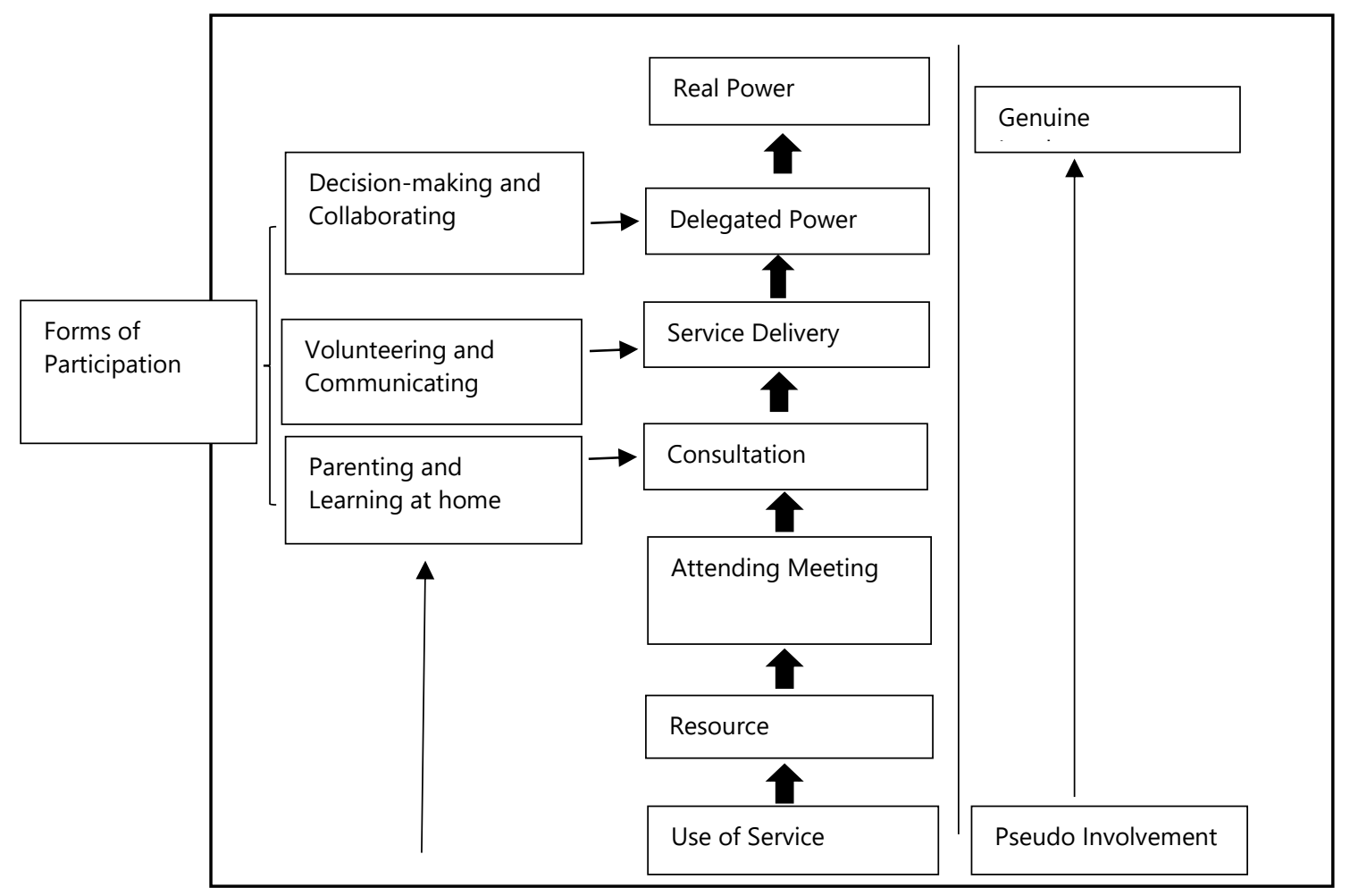

Figure 1. A summary of levels of community participation 


\subsection{Qualitative research findings}

\subsubsection{Characteristics of interview key informants}

For qualitative phase, the key informants included 19 personnel comprising the principal of the school, 4 teachers, 3 community leaders, 8 school committee members and 3 parents who had experience in participation.

\subsubsection{Interview results on types of community participation}

One of the key findings of the qualitative method application was that the majority of the community members of Taungzalat School had a positive attitude towards education, getting good education was very important for their children. The common views among them on community involvement was that distributing financial help and materials to the body of school for improving school and education is important.

Interview results confirmed the quantitative findings by revealing that, apart from teacher and school staff, the most involved groups in children learning and school development were parents of the students, members of the school committee, and local authorities. Students' parents more directly participated at home than at school, while local authorities and members of school committee participated more directly in school development.

Regarding parenting and learning at home, observation revealed that parents and siblings of children, especially those who had little kids, took their children to school and picked them up after school. Parents also had alternative ways if they themselves could not take or pick up their children.

In terms of communication between school and community, one of the ways to disseminate the information about school activities and development was annual meeting, held three times a year. The second way to spread news and information about school activities and school development to all community members was fulfilled through students, members of school committee and local authorities. In fact, if the school had an upcoming meeting, they would 1) ask students to deliver invitation letters to their parents, 2) ask local authorities to make announcement about an upcoming meeting, and 3) ask members of school committee to deliver invitation letters to homes where students could not reach. Communication between school (teachers) and parents was commonly carried out through parents' visits to school, formal written communication tools, phone calls, and teacherparent meetings. Most effective and convenient ways to discuss children's learning and behaviors at school seemed to be phone calls and teacher-parent meetings.

Volunteering activities of community members found in the interview results were encouraging children in the community to attend school and sharing educational information in the community. The community members were inspired by a common purpose to improve education for the next generation. They all believed that education would equip the next generation well to become efficient leaders or get well-paid jobs. However, these stakeholders too much focused on participating through contributing physical materials in education that consumed significant community resources.

Another important finding of the interview was that school boards and community leaders were working closely with schools to develop education, including fundraising and school maintenance. Schools always discussed school projects, challenges and school development plans with school boards and parents. School committees represented community members of the school. The committee participated in most phases of education and school development, such as school development planning, budget management and mobilization of local resources. 


\subsubsection{The formation, structure, and administration system of Taungzalat Primary School}

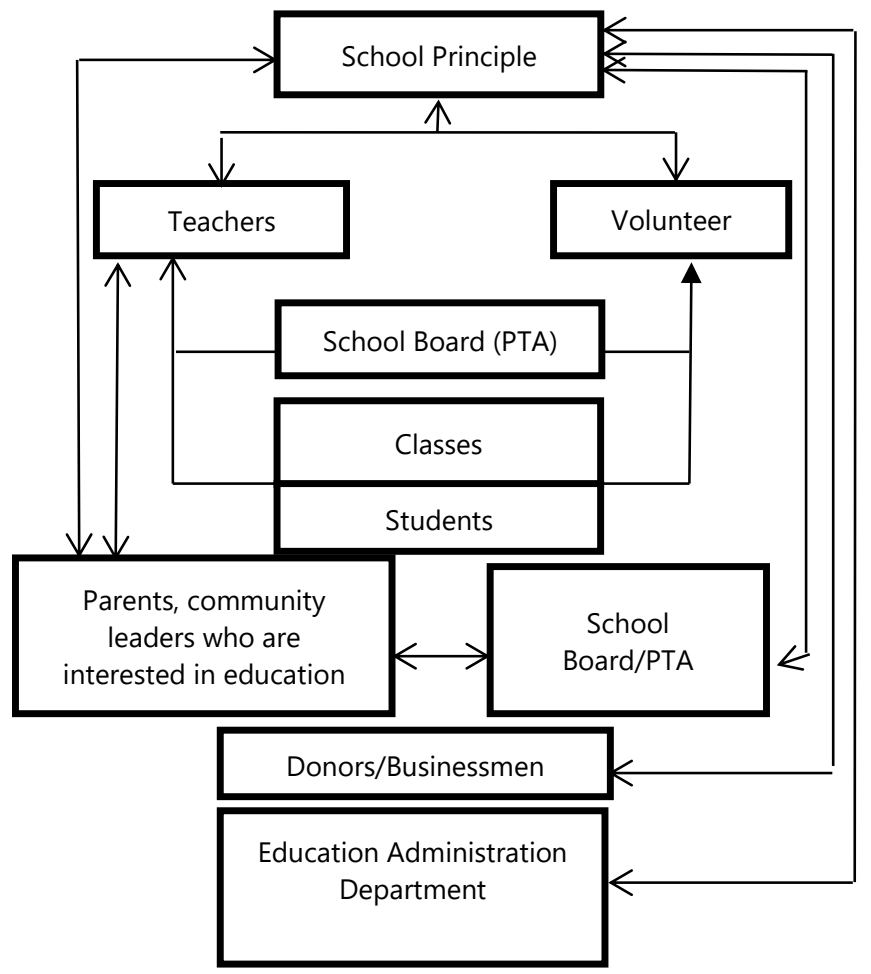

Figure 2. The formation, structure, and administration system of Taungzalat Primary School

These data were collected from school documents and records. Taungzalat Primary School was founded as a self-supported school; however, the school was later developed and recognized as a public primary school by the Ministry of Education, Myanmar. According to the results from document as seen in Figure 2, within the TPS School, the principal is the head of the school who makes sure that the school runs properly in accordance with rules and regulation of MoE, Myanmar. The principal is also the key person in planning, drawing strategies, and implementing those strategies for school success and students' academic achievement. Schoolteachers and volunteer teachers in cooperation with school board (PTA), community leaders, and parents supported the principal. In this school, businesspersons (donors) and community leaders also played important roles in administration system. Education Administration Department (EAD) heads the TPS. EAD oversees and monitors TPS to function properly according to the rules and regulation of $\mathrm{MoE}$, Myanmar. EAD also gives consultation related to school planning and primary education (See Figure 2). 


\subsubsection{The formation, structure, and administration system of Taungzalat community}

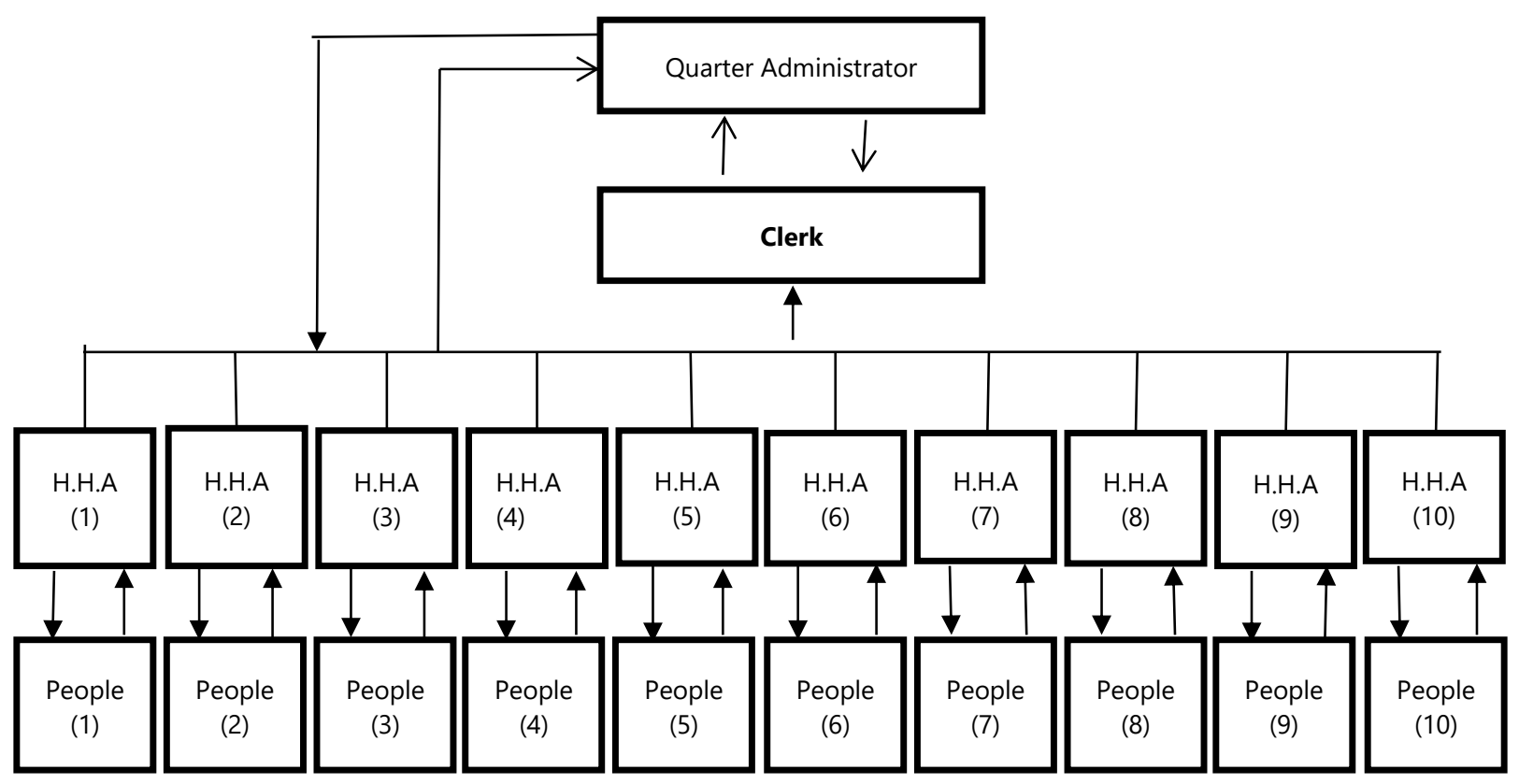

H.H.A = Hundred Household Administrator

Figure 3. The formation, structure, and administration system of Taungzalat community

Similarly, these data were collected from Taungzalat community documents and records. In Taungzalat community, there is one community head (chief administrator), ten hundred household administrators and one clerk. All of them are appointed by the community, and they are responsible for improving the community in every aspect including peace, safety, education, and mobilization for a common cause - designing courses of community action in order to overcome the challenges with dedication, honesty and integrity (see figure 3).

\section{Discussion}

Scholars on child behavior development generally have accepted the assumption that parents as primary caregivers probably have the greatest impact on child development (Pretorius, 2000). Thus, child development is greatly influenced by the parenting style, environment and culture (Zaman, et al., 2014). The results from activities found in this study support routine schooling, such as taking children to school and preparing children for school with study materials and proper dressing. Parents have also reported that they have approached the teacher to obtain information about their child's progress. They discussed their children's learning and progress with teachers. These activities are considered parenting because parents have created opportunities for their children to obtain knowledge through education (Epstein \& Salinas, 2004; To, 2016). These findings are best aligned with the previous study conducted by To (To, 2016). Participation showed that parents have taken care of their children's future. They responded to government policies that encourage parents to send their children to school and help their children with schooling. It also reflects parents' understanding of the value of education. 
Analysis of data showed that parents helped their children study at home after school. The ways of parent participation found in the study are supporting their children with study through teaching and checking on a daily basis if their children have finished schoolwork and homework. Most parents encouraged their children and asked them to study before they go to bed. The findings are consistent with Nguon (2012) and To (2016). The school encouraged parents to send their children to school and advised parents to provide learning support to their children. However, specific knowledge was not provided to parents and caregivers concerning the ways to help children with their learning and achieve challenges. This indicated that parenting knowledge (Epstein, 2010; To, 2016), which is important for improving child learning, was not the focus of the school. This might be because the government has not paid any attention to these skills.

Parental involvement in two forms of parenting and learning at home fell at the moderate level in the table of degree of parental involvement by To (2016). Despite the absence of evidence for taking part in decision making, the results showed that parents participated in discussions and informal talks. These two types of participation were, therefore, undoubtedly at the level of consultation. According to Bray (2000), counseling is about the extent to which participants share information and discuss educational programs and the progress of their children.

In terms of communication, it was clear that parents, community members and school shared school information by different means of communication, including meetings, written and oral communication tools. These findings are consistent with Epstein's theory and previous research conducted by To (2016), and Nguon (2012), indicating that community members (parents or non-parents) of the students, local authorities and other stakeholders have received updated information from meetings, letters and telephone communication. For school development, school communicated with community members and parents through meetings, and those who attended the meetings disseminated information to the community members who did not attend, so that members of the community could understand the value of education and participated in children's learning. This process meant that parents and community members have participated in communicating and interpreting educational information to a wider community. Local authorities and school boards were also found to participate using a variety of means of communication, such as meetings, telephone calls and school visits. These activities are considered as communicating activities (Epstein and Salinas, 2004). The school has helped community, parents and school committee spread information to a broader community, especially to the members with lower levels of information literacy. These results showed that communication through phone calls was used to communicate formally about children's learning outcomes between schools and parents. This kind of communication was more appropriate and effective than written communication with parents whose ability to read and write are low (Epstein, 2018; To, 2016). Other options that could be applied, too, such as meetings and home visits. They, together with phone calls, require more effort from the teacher and the parent.

Regarding volunteering, research showed that there were a group of 8 persons volunteering as paid teachers and a group of 16 community members working with schools to develop and improve schools as volunteer groups. A school board member was a community representative of a school composed of multiple members, such as local authorities, retired teachers, teachers, and parents. The school board members participated in meetings with teachers to develop school development plans, discuss school and educational development, and conduct fundraising activities for school development. These results are consistent with Epstein's Theory (Epstein, 2010) and results by To (2016). Students also volunteered for school environmental clean-up, school safety and other school voluntary service activities. Community members, family and local authorities also volunteered by participating at school meetings and at some school events. Because this area seemed to be left to teachers, I could not find any voluntary activity related to teachers helping to develop the classroom and curriculum. These results showed that community members are actively contributing to the improvement of schools and education. It has been reported that people in the 
community were active in disseminating educational information. The nature of community and parental involvement in the above education is consistent with the fifth level of participation.

Participation in decision making is involvement of parents and community members in school advocacy for school decision making, management, and school and educational development through school boards (Hornby, 2011; Epstein, \& Salinas, 2004). It was clear that the school committee had a variety of rights and certain powers in the decision-making process, especially in school buildings and road construction. This finding was best aligned with the views of Botes and Van Rensburg (2000), indicating, to some extent, that school committees have represented the views and perspectives of parents. The school and the school committee were observed to have the power shared in the decision-making process in budget planning and monitoring the school. Schools worked in partnership with the school committee to develop school, in which the power was distributed. These findings are consistent with Epstein's (2010) theory. Based on Bray (2000), it has become clear that genuine participation occurs as power is dispersed between community and school. However, school committees were not invited while making decision for curriculum development and teaching methods.

In terms of collaborating between school and community, research showed that the most common form of participation in education was resource contribution. Community members, local authorities and family donated available resources such as money, materials and labor to school fees and environmental improvements when the school asked for it. As government budget was not enough, their contributions have been found to be important for school development. The practices reported in this study reflect Rose's (2003) claim that community contributions are desirable when public resources are not sufficient. These findings are consistent with Sanders (2001) in terms of factors that improve community involvement in education. Community, parents and school collaborative activities have been reported to occur at different levels, from resource allocation to power withdrawn. Local communities, parents, students, teachers, and local authorities reportedly worked in partnership in fundraising and networking for child safety. This engagement indicated that the community and the teachers respected each other in decision making. Thus, cooperative participation can be assumed as reaching the level of Bray's "delegated power."

\section{Recommendations}

This study provides a better understanding of community involvement in Myanmar education. It is recommended that:

1. the school management team uses the results of this study to reflect their approach to community involvement in schools;

2. decision makers involving in educational policies of local and national government agencies should be informed of these results in connection with developing community participation policies for educational services.

3. Further research into community participation in education in Myanmar could be useful in several areas. It is desirable to conduct:

4. a study on the effect of community and parent involvement on students learning;

5. a correlation study to investigate relationship between community involvement and primary, middle and high school students' academic performance factors - to name a few: achievement, attendance, attitude toward school and student engagement; 
6. research focusing not only on the ways how community resources are mobilized, but also on how local people should be engaged more in children's learning process.

\section{Acknowledgement}

The authors are thankful to all friends and participants who helped to accomplish this research as well as to Thailand's Educvation Hub NAESA for Southern Region (CA-TEH) and Social Development Department, Faculty of Humanities and Social Sciences, Prince of Songkla University for funding this research.

\section{References}

Altschul, I. (2011). Parental involvement and the academic achievement of Mexican American youths: what kinds of involvement in youths' education matter most? Social Work Research, 35(3), 159-170.

Baird, A. S. (2015). Beyond the Greatest Hits: A counterstory of English learner parent involvement. School Community Journal, 25(2), 153-175.

Banerjee, M., Harrell, Z. A. and Johnson, D.J. (2011). Racial/ethnic socialization and parental involvement in education as predictors of cognitive ability and achievement in African American children. Journal of Youth and Adolescence, 40(5), 595605.

Botes, L. \& Van Rensburg, D. (2000). Community participation in development: Nine plagues and twelve commandments. Community Development Journal, 35(1), 41-58.

Bray, M. (2000). Community Partnership in Education: Dimensions, Variations, and Implications. Paris: UNESCO.

Cheung, C.S.S., \& Pomerantz, E.M. (2015). Value development underlies the benefits of parents' involvement in children's learning: A longitudinal investigation in the United States and China. Journal of Educational Psychology, 107(1), 309-320.

Cole, S. (2005). Cultural tourism, community participation and empowerment. In Robinson, M. \& Phipps, A. (Eds.). Cultural Tourism in a Changing World, 89-103. Clevedon, UK: Channel view publications.

Derrick-Lewis, S. M. (2001). Parental Involvement Typologies as Related to Student Achievement. Published PhD thesis. Johnson City, Tennessee: East Tennessee State University.

Driessen, G., Smit, F., \& Sleegers, P. (2005). Parental involvement and educational achievement. British Educational Research Journal, 31(4), 509-532.

El Nokali, N.E., Bachman, H.J. \& Votruba-Drzal, E. (2010). Parent involvement and children's academic and social development in elementary school. Child Development, 81(3), 988-1005.

Epstein, J.L. (1987). Parent involvement: What research says to administrators. Education and Urban Society, 19(2), 119-136.

Epstein, J.L. (2018). School, Family, and Community Partnerships: Preparing Educators and Improving Schools. New York: Routledge. 
Epstein, J.L. (2010). School, family, community partnerships: Caring for the children we share. Phi Delta Kappan, 92(3), 81-96.

Epstein, J.L. \& Salinas, K.C. (2004). Partnering with families and communities. Educational leadership, 61(8), 12-19.

Epstein, J.L., Sanders, M. G., Sheldon, S.B., Simon, B.S., Salinas, K.C., Jansorn, N.R. and Hutchins, D.J. (2018). School, Family, and Community Partnerships: Your Handbook for Action. Washington, D.C: Corwin Press.

Epstein, J. L. \& Sheldon, S. B. (2002). Present and accounted for: Improving student attendance through family and community involvement. The Journal of Educational Research, 95(5), 308-318.

Henderson, A.T. (2007). Beyond the Bake Sale: The Essential Guide to Family-School Partnerships. New York: The New Press.

Hoover-Dempsey, K.V., Walker, J.M., Sandler, H.M., Whetsel, D., Green, C.L., Wilkins, A.S. and Closson, K. (2005). Why do parents become involved? Research findings and implications. The Elementary School Journal, 106(2), 105-130.

Hornby, G. (2011). Parental Involvement in Childhood Education: Building Effective School-Family Partnerships. New York: Springer Science \& Business Media.

Mautone, J.A., Marcelle, E., Tresco, K.E., \& Power, T.J. (2015). Assessing the quality of parent-teacher relationships for students with ADHD. Psychology in the Schools, 52(2), 196-207.

McNeal, R.B., Jr. (2012). Checking in or checking out? Investigating the parent involvement reactive hypothesis. The Journal of Educational Research, 105(2), 79-89.

Mombourquette, C.P. (2007). A Study of the Relationship between the Type of Parent Involvement and High School Student Engagement, Academic Achievement, Attendance, and Attitude toward School. Published PhD Thesis. Missoula, Montana: University of Montana.

Nitecki, E. (2015). Integrated school-family partnerships in preschool: Building quality involvement through multidimensional relationships. School Community Journal, 25(2), 195-219.

Nguon, S. (2012) Parental involvement and students' achievement in Cambodia: Focusing on parental resourcing of public schooling. International Journal of Educational Research, 53, 213-224.

Pretorius, N. (2000). Aspects of Parenting Styles and the Expressed Fears of a Selected Group of Pre-school Children. Published MA thesis. Stellenbosch: Stellenbosch University.

Reynolds, A.J., Temple, J.A., Robertson, D.L., \& Mann, E.A. (2001). Long-term effects of an early childhood intervention on educational achievement and juvenile arrest: A 15-year follow-up of low-income children in public schools. Jama, 285(18), 2339-2346.

Rodriguez, R.J., Blatz, E.T., \& Elbaum, B. (2014). Parents' views of schools' involvement efforts. Exceptional Children, 81(1), 79-95.

Rose, P. (2003). Community participation in school policy and practice in Malawi: Balancing local knowledge, national policies and international agency priorities. A Journal of Comparative and International Education, 33(1), 47-64.

Sanders, M.G. (2001). The role of community in comprehensive school, family, and community partnership programs. The Elementary School Journal, 19-34.

Smith, M. \& Brahce, C.I. (1962). Focus on Achievement. Flint, Michigan: Public School.

Smith, D. (2003). Five principles for research ethics. Monitor on psychology, 34(1), 56-60. 
To, L. (2016). Community Participation in Education: A Case Study in the Four Remote Primary Schools in Samlot District, Battambang Province, Cambodia. Published Master's thesis. Wellington, New Zealand: University of Wellington.

Topper, A.M., \& Powers, J.M. (2013). Democracy's college: The American community college in the 21st century: Framing the issue. Education Policy Analysis Archives, 21 (14), 1-9.

Vera, E.M., Israel, M.S., Coyle, L., Cross, J., Knight-Lynn, L., Moallem, I., Goldberger, N. (2012). Exploring the educational involvement of parents of English learners. School Community Journal, 22(2), 183-202.

Washington, L. (2016). The Effects of Parent Involvement on Student Outcomes in a Minority-Serving Charter High School. Published Ph.D. thesis. Minneapolis: Walden University.

Win, D. (2014). Community Participation in Education in Myanmar. Retrieved July 19, 2019 from: https://delly009.wordpress.com

Williams, V.L. (2017). Relationship between Parents' Attitudes and Involvement in an Elementary School. Doctoral dissertation. Minneapolis: Walden University.

Zaman, R., Arslan, M., Malik, R.K., \& Mehmood, A. (2014). Effect of parenting style on child behavior: A Qualitative Analysis. Journal of Education and Practice, 5, 112-118. 